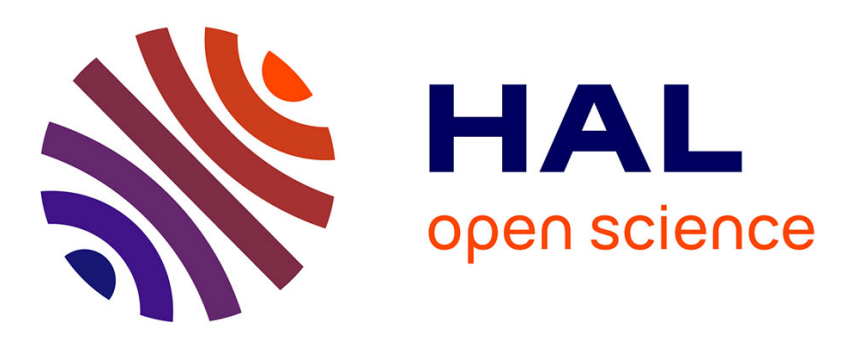

\title{
Isolated Cryptorchidism: No Evidence for Involvement of Genes Underlying Idiopathic Hypogonadotropic Hypogonadism
}

\author{
Eeva-Maria Laitinen, Johanna Tommiska, Helena E. Virtanen, Heidi
}

Oehlandt, Rosanna Koivu, Kirsi Vaaralahti, Jorma Toppari, Taneli Raivio

\section{To cite this version:}

Eeva-Maria Laitinen, Johanna Tommiska, Helena E. Virtanen, Heidi Oehlandt, Rosanna Koivu, et al.. Isolated Cryptorchidism: No Evidence for Involvement of Genes Underlying Idiopathic Hypogonadotropic Hypogonadism. Molecular and Cellular Endocrinology, 2011, 341 (1-2), pp.35. 10.1016/j.mce.2011.05.015 . hal-00719875

\section{HAL Id: hal-00719875 \\ https://hal.science/hal-00719875}

Submitted on 22 Jul 2012

HAL is a multi-disciplinary open access archive for the deposit and dissemination of scientific research documents, whether they are published or not. The documents may come from teaching and research institutions in France or abroad, or from public or private research centers.
L'archive ouverte pluridisciplinaire HAL, est destinée au dépôt et à la diffusion de documents scientifiques de niveau recherche, publiés ou non, émanant des établissements d'enseignement et de recherche français ou étrangers, des laboratoires publics ou privés. 


\section{Accepted Manuscript}

Isolated Cryptorchidism: No Evidence for Involvement of Genes Underlying Idiopathic Hypogonadotropic Hypogonadism

Eeva-Maria Laitinen, Johanna Tommiska, Helena E. Virtanen, Heidi Oehlandt, Rosanna Koivu, Kirsi Vaaralahti, Jorma Toppari, Taneli Raivio

PII: S0303-7207(11)00257-7

DOI: 10.1016/j.mce.2011.05.015

Reference: $\quad$ MCE 7848

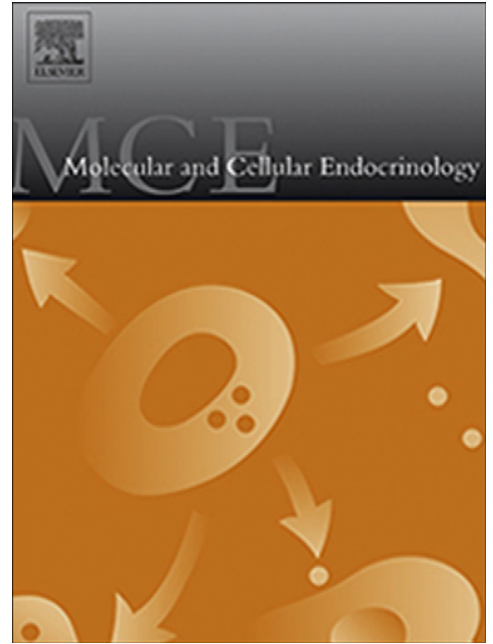

To appear in: $\quad$ Molecular and Cellular Endocrinology Molecular and Cellular Endocrinology

Received Date: $\quad 14$ December 2010

Revised Date: $\quad 12$ April 2011

Accepted Date: $\quad 6$ May 2011

Please cite this article as: Laitinen, E-M., Tommiska, J., Virtanen, H.E., Oehlandt, H., Koivu, R., Vaaralahti, K., Toppari, J., Raivio, T., Isolated Cryptorchidism: No Evidence for Involvement of Genes Underlying Idiopathic Hypogonadotropic Hypogonadism, Molecular and Cellular Endocrinology Molecular and Cellular Endocrinology (2011), doi: 10.1016/j.mce.2011.05.015

This is a PDF file of an unedited manuscript that has been accepted for publication. As a service to our customers we are providing this early version of the manuscript. The manuscript will undergo copyediting, typesetting, and review of the resulting proof before it is published in its final form. Please note that during the production process errors may be discovered which could affect the content, and all legal disclaimers that apply to the journal pertain. 


\section{Isolated Cryptorchidism: No Evidence for Involvement of Genes}

\section{Underlying Idiopathic Hypogonadotropic Hypogonadism}

3 Eeva-Maria Laitinen ${ }^{\mathrm{a}, \mathrm{b}}$, Johanna Tommiska ${ }^{\mathrm{a}, \mathrm{b}}$, Helena E. Virtanen ${ }^{\mathrm{c}}$, Heidi Oehlandt ${ }^{\mathrm{c}}$, Rosanna Koivu ${ }^{\mathrm{b}}$,

4 Kirsi Vaaralahti ${ }^{\text {a,b }}$, Jorma Toppari ${ }^{\text {c }}$, and Taneli Raivio ${ }^{\text {a,b }}$

$5 \quad{ }^{a}$ Children's Hospital, Helsinki University Central Hospital, University of Helsinki, FI-00029 Helsinki,

6 Finland

$7 \quad{ }^{\mathrm{b}}$ Institute of Biomedicine/Physiology, Biomedicum Helsinki, University of Helsinki, FI-00014 Helsinki,

8 Finland

$9 \quad{ }^{\mathrm{c}}$ Departments of Physiology and Pediatrics, University of Turku, FI-20520 Turku, Finland.

Address all correspondence to Dr. Taneli Raivio M.D. Ph.D., Institute of Biomedicine/ Department of

11 Physiology, University of Helsinki, Biomedicum Helsinki, P.O. Box 63 (Haartmaninkatu 8), FI-00014

12 Helsinki, Finland. Telephone: +358 9 19125287; Telefax: +358 9 19125302; E-mail:

13 taneli.raivio@helsinki.fi 


\section{Abstract}

Mutations in FGFR1, GNRHR, PROK2, PROKR2, TAC3, or TACR3 underlie isolated hypogonadotropic hypogonadism (IHH) with clinically variable phenotypes, and, by causing incomplete intrauterine activation of the hypotalamic - pituitary - testicular axis, may lead to cryptorchidism. To investigate the role of defects in these genes in the etiology of isolated cryptorchidism, we screened coding exons and exon-intron boundaries of these genes in 54 boys or men from 46 families with a history of cryptorchidism. Control subjects (200) included 120 males. None of the patients carried mutation(s) in FGFR1, PROK2, PROKR2, $T A C 3$ or TACR3. Two of the 46 index subjects with unilateral cryptorchidism were heterozygous carriers of a single GNRHR mutation (Q106R or R262Q), also present in male controls with a similar frequency (3/120; $p=0.62$ ). No homozygous or compound heterozygous GNRHR mutations were found. In conclusion, cryptorchidism is not commonly caused by defects in genes involved in IHH.

\section{Keywords: Cryptorchidism, FGFR1, GNRHR, PROK2, PROKR2, TAC3, TACR3}

Abbreviations: $F G F R 1$, fibroblast growth factor receptor 1; GNRHR, gonadotropin-releasing hormone receptor; $P R O K 2$, prokineticin 2; PROKR2, prokineticin receptor 2; TAC3, tachykinin 3; TACR3, tachykinin receptor 3; IHH, isolated hypogonadotropic hypogonadism; AR, androgen receptor; INSL3, insulin-like factor 3; RXFP2, relaxin/insulin-like family peptide receptor 2 


\section{Introduction}

Cryptorchidism is one of the most common malformation in full-term boys with an estimated prevalence of 2-8\% (Virtanen et al., 2007a), and an increasing incidence (Boisen et al., 2004). Testicular development and descent is a multifaceted process affected by anatomical, hormonal, environmental, and genetic factors (Damgaard et al., 2008; Foresta et al., 2008; Main et al., 2010; Skakkebaek et al., 2001; Virtanen et al., 2007a; Virtanen et al., 2007b). Mutations in the androgen receptor gene $(A R)$ appear a rare cause of isolated congenital cryptorchidism (Ferlin et al., 2008). Recently, variation in the genes encoding insulin-like factor 3 (INSL3) that regulates the first, transabdominal phase of testicular descent (at least in mice) and in its receptor, RXFP2 (LGR8), has been described in patients with congenital cryptorchidism (Ferlin et al., 2008; Foresta et al., 2008; Virtanen et al., 2007b). However, the reported role of these variants in the etiology of cryptorchidism is not consistent because of contradictory results (Ars et al., 2010; El Houate et al., 2008; Koskimies et al., 2000; Krausz et al., 2000; Lim et al., 2001; Nuti et al., 2008; Roh et al., 2003). Thus, relatively little is known about the genetic factors regulating testicular descent in humans.

Androgens have a pivotal role in testicular descent (Foresta et al., 2008). We have previously found reduced androgen bioactivity in 3-month-old boys with severe persistent cryptorchidism (Raivio et al., 2003), although immunoreactive testosterone levels did not show any differences between cases (all types included) and controls (Suomi et al., 2006). Expectedly, defects in the hypothalamic-pituitary-testicular (HPG) axis typically lead to cryptorchidism, a relatively common phenotypic feature in patients with isolated hypogonadotropic hypogonadism (IHH) (Pitteloud et al., 2002). It appears unlikely, however, that gene defects underlying IHH would account for isolated cryptorchidism, because these patients usually do not present with micropenis and may have slightly elevated rather than low gonadotropin levels during the minipuberty of infancy (Suomi et al., 2006). On the other hand, some IHH patients carrying mutation(s) in FGFR1, GNRHR, PROK2/PROKR2 or TAC3/TACR3 have displayed recovery of their hypogonadotropism (Gianetti et al., 2010; Pitteloud et al., 2005; Raivio et al., 2007; Sinisi et al., 2008), a phenomenon described also in a pediatric patient with an FGFR1 mutation: this proband had bilateral cryptorchidism without 
micropenis, but underwent spontaneous puberty as a teenager (Zenaty et al., 2006). It is currently unknown whether such reversal of hypogonadotropism could occur earlier, already during the first few months of life.

Very recently, Caronia et al. (2011) found six heterozygous rare variants in genes underlying IHH (two in FGFR1 (G260E and R765H), two in PROKR2 (R85H and L173R), one in GNRHR (R262Q), and one in $K A L 1$ (V371I)) in women with hypothalamic amenorrhea, and suggested that these variants may cause at least partial susceptibly to HPG axis disorders. We recently reported a relatively high carrier frequency of two GNRHR mutations (Q106R and R262Q), both leading to partial inactivation of the receptor (de Roux et al., 1997; Layman et al., 1998), in Finnish population (altogether 5/200; 2.5\%) (Vaaralahti et al., 2011). We therefore hypothesized that some patients with homozygous or compound heterozygous GNRHR mutations, or with rare variants in other genes underlying IHH, could present with cryptorchidism as a phenotypic sign of partially deficient GnRH signaling.

We investigated 54 Finnish boys or men from 46 families with a history of cryptochidism for mutations in FGFR1, GNRHR, PROK2, PROKR2, TAC3, and TACR3. The roles of INSL3 and RXFP2 in cryptorchidism have been previously studied in Finnish population, but only common polymorphisms were found with similar frequencies in cases and controls (Koskimies et al., 2000; Roh et al., 2003).

\section{Subjects and Methods}

\subsection{Subjects}

Altogether 54 subjects were included from 46 families. Of these 54 subjects, 13 had bi- and 39 had unilateral cryptorchidism, and information on the type of cryptorchidism in 2 cases was unavailable. Familial form of cryptorchidism, i.e. a cryptorchid first degree relative, was reported in 19 of the 46 participating families. Of the 54 subjects, 34 boys were followed up from birth and 33 of them had cryptorchidism diagnosed at birth (in preterm cases the diagnosis was verified at the expected date of delivery), and one boy was diagnosed at the age of 18 months. Boys were clinically examined after birth and at a mean age of 3 months, and were followed up until the age of 18 months. None of them had micropenis. The familial cases included 5 boys with bilateral (two of them were brothers) and 4 with unilateral cryptorchidism. Of the 34 subjects followed 
up from birth, 19 boys of whom we had hormonal data at minipuberty all had normal gonadotropin and sex steroid levels during the minipuberty of infancy (Suomi et al., 2006) and puberty has started in 16 boys. Of the remaining 15/34 boys, 12 have by far displayed normal onset of puberty excluding classical IHH. Six boys, of whom 3 had normal hormone levels at minipuberty, are still too young to determine the onset of puberty, but they are being actively followed up. During the course of the follow-up, spontaneous descent of the testis was observed in 12 of the 34 boys.

In addition, 13 families including 20 male subjects participated via study on the familial incidence of cryptorchidism. Six of these male subjects reported of having congenital cryptorchidism. Of the 20 males, 19 had been previously treated for cryptorchidism, and one boy had had a spontaneous recovery of cryptorchidism. None of them displayed penile anomalies in infancy. In two families the fathers had unilateral and the sons had bilateral cryptorchidism; in three families, both the fathers and the sons had unilateral cryptorchidism; in one family, both brothers had unilateral cryptorchidism; and, in one family, the son had bilateral cryptorchidism and the type of the father's cryptorchidism remained unknown. In addition, three male subjects with unilateral cryptorchidism had a cryptorchid first degree relative. Unfortunately, the presence or absence of hypogonadism and the data on pubertal development of these subjects and their family members were unavailable. In one family, however, the pregnancy had been induced by microinjection, and both son and the father had cryptorchidism and were included in this study. No assisted reproductive techniques were used in 10 families, and in 2 families this information was unavailable.

Two hundred (120 males, 80 females) control subjects were included from the same geographical region. DNA was obtained from a blood sample. The study was accepted by the joint ethics committee of Turku University and Turku University Hospital, and informed consent was obtained from the participants or guardians of the participating boys.

\subsection{Mutation screening of FGFR1, GNRHR, PROK2, PROKR2, TAC3, and TACR3}

Genomic DNA from peripheral blood leukocytes of the subjects was extracted, and the coding exons and exon-intron boundaries of FGFR1, GNRHR, PROK2, PROKR2, TAC3, and TACR3 were PCR amplified and screened by direct sequencing. In addition, exons 1-3 of the GNRHR were screened in control DNA in 200 
(120 males, 80 females) subjects. PCR products were purified with ExoSAP-IT treatment (Amersham Biosciences, Piscataway, NJ, USA), and sequenced using the ABI BigDyeTerminator Cycle Sequencing Kit (v3.1) and ABI Prism 3730xl DNA Analyzer automated sequencer (Applied Biosystems, Foster City, CA, USA). The sequences were aligned and read with Sequencher® 4.9 software (Gene Codes Corporation, Ann Arbor, MI, USA). All primer sequences and PCR conditions are available upon request.

\subsection{Statistical analysis}

All $p$-values are two-sided, and $p<0.05$ was considered significant. Fisher's exact test was used to determine statistical significance between cases and controls (Simple Interactive Statistical Analysis, SISA, http://www.quantitativeskills.com/sisa/).

\section{Results}

\subsection{Mutation screening of FGFR1, GNRHR, PROK2, PROKR2, TAC3, and TACR3}

We investigated 54 subjects with a history of cryptorchidism from 46 families for mutations in the FGFRl, GNRHR, PROK2, PROKR2, TAC3, and TACR3. We did not identify mutations in the coding regions of FGFR1, PROK2, PROKR2, TAC3, or TACR3. However, two unrelated subjects, both with a positive family history of cryptorchidism in a first-degree relative, carried a heterozygous missense mutation, Q106R or R262Q, in GNRHR. Both subjects had unilateral cryptorchidism and neither of them had a spontaneous descent of a testis. The subject with R262Q mutation and his parents had normal onset of puberty, but the father had been operated for cryptrochidism. The second subject carrying a Q106R mutation had normal fertility, and his son had congenital cryptorchidism. Unfortunately, affected family members of these two subjects were unavailable for the analysis. These heterozygous missense GNRHR mutations were also present in 2 and 3 of 200 controls ( 2 and 1 of 120 males), respectively. Thus, the prevalence of the missense mutations between 46 index subjects and male controls did not differ $(p=0.62)$. 


\section{Discussion}

129

130

131

132

133

134

We hypothesized that some patients with isolated cryptorchidism might harbor defects in genes previously shown to be indispensable for the intact function of the hypothalamic-pituitary-gonadal axis. Recently, Sykiotis et al. (2010) showed that some patients with IHH also have testicular defects, and Hadziselimovic et al. (2010) reported reduced expression of FGFRl in cryptorchid testis as compared to normally descended testis analyzed in testicular biopsies. Carriers of FGFR1 mutations may have wide a phenotypic spectrum ranging from healthy carriers to severe IHH and Kallmann syndrome (IHH and decreased/absent sense of smell) (Dode et al., 2003; Pitteloud et al., 2005). However, none of the boys in the current study displayed mutations in the coding regions of FGFRl, suggesting that cryptorchidism is not commonly caused by IHHcausing FGFRl mutations with incomplete penetrance. Because we used DNA obtained from peripheral blood leukocytes, we cannot formally rule out, however, the possibility of tissue mosaicism of $F G F R I$ mutations, previously described in a family with an IHH proband (Sato et al., 2006).

Two subjects with cryptorchidism carried a heterozygous missense change, Q106R or R262Q, in GNRHR.

These mutations have previously been described in homozygous or compound heterozygous state in patients with IHH, delayed puberty, or with IHH but spontaneous pregnancy (Beranova et al., 2001; Caron et al., 1999; de Roux et al., 1997; Dewailly et al., 2002; Lin et al., 2006), whereas heterozygous carriers of these mutations were unaffected (Beranova et al., 2001; de Roux et al., 1997). On the other hand, R262Q was recently found in heterozygous state in a woman with hypothalamic amenorrhea (Caronia et al., 2011). However, we found that the frequency of heterozygous Q106R or R262Q GNRHR mutations did not differ between cases and male controls, and we therefore conclude that these heterozygous GNRHR mutations do not contribute to the prevalence of common cryptorchidism.

Neurokinin B and prokineticin signaling appears indispensable for HPG axis function in boys during late gestation and minipuberty of infancy, as evidenced by high frequency of micropenis among male IHH probands with $P R O K 2$, PROKR2, TAC3, or TACR3 mutations (Abreu et al., 2008; Gianetti et al., 2010; Sarfati et al., 2010; Topaloglu et al., 2009). Since none of our subjects had micropenis or reported penile 
153

154

155

anomalies, it was somewhat predictable that none of the subjects carried mutations in TAC3,TACR3, PROK2, or PROKR2.

The limitation of this study is a relatively small sample size. However, if mutation(s) in FGFR1, GNRHR, TAC3, TACR3, PROK2, or PROKR2 did cause $10 \%$ of cryptorchidism, we would have with $99 \%$ probability found at least one case with conclusive mutation(s) among 46 index subjects. Similarly, if the prevalence of the mutation(s) was $4 \%$, the probability to detect at least one is still $85 \%$. Finally, the familial occurrence of cryptorchidism supports the genetic etiology for the condition (Weidner et al., 1999), and the risk for cryptorchidism in male infant is increased if a brother or father is affected (Elert et al., 2003; Foresta et al., 2008). In this study, $41 \%$ (19/46) of participating families had more than one cryptorchid family member, but high familial incidence herein was due to specific selection of the familial cases.

In conclusion, our results show that IHH-causing FGFRl mutations with incomplete penetrance, or homozygous/compound heterozygous GNRHR, PROK2, PROKR2, TAC3, or TACR3 mutations are not frequently encountered in patients with isolated cryptorchidism. It is therefore unlikely that mutations in these genes would contribute significantly to the prevalence of isolated cryptorchidism. Despite this, the familial cases suggest that there is a genetic susceptibility to common cryptorchidism.

Funding: This work was supported by grants from the Helsinki University Central Hospital Research Funds, Academy of Finland, Sigrid Juselius Foundation, Foundation for Pediatric Research, Emil Aaltonen Foundation, Research Foundation of the University of Helsinki, Jalmari and Rauha Ahokas Foundation, Orion-Farmos Research Foundation, Finnish Cultural Foundation, Novo Nordisk Research Foundation, Turku University Hospital Research Funds, and the European Commission (DEER 212844 FP7-ENV-20071).

Declaration of interest: The funding sources had no impact on the design or performance of the study, and there were no competing interests for any of the authors in relation to this manuscript.

\section{References}


Abreu, A.P., Trarbach, E.B., de Castro, M., Frade Costa, E.M., Versiani, B., Matias Baptista, M.T., Garmes, H.M., Mendonca, B.B., Latronico, A.C., 2008. Loss-of-function mutations in the genes encoding prokineticin-2 or prokineticin receptor-2 cause autosomal recessive Kallmann syndrome. J. Clin. Endocrinol. Metab. 93, 4113-4118.

Ars, E., Lo Giacco, D., Bassas, L., Nuti, F., Rajmil, O., Ruiz, P., Garat, J.M., Ruiz-Castane, E., Krausz, C., 2010. Further insights into the role of T222P variant of RXFP2 in non-syndromic cryptorchidism in two Mediterranean populations. Int. J. Androl. DOI: 10.1111/j.1365-2605.2010.01088.x.

Beranova, M., Oliveira, L.M., Bedecarrats, G.Y., Schipani, E., Vallejo, M., Ammini, A.C., Quintos, J.B., Hall, J.E., Martin, K.A., Hayes, F.J., Pitteloud, N., Kaiser, U.B., Crowley, W.F.,Jr, Seminara, S.B., 2001. Prevalence, phenotypic spectrum, and modes of inheritance of gonadotropin-releasing hormone receptor mutations in idiopathic hypogonadotropic hypogonadism. J. Clin. Endocrinol. Metab. 86, 1580-1588.

Boisen, K.A., Kaleva, M., Main, K.M., Virtanen, H.E., Haavisto, A.M., Schmidt, I.M., Chellakooty, M., Damgaard, I.N., Mau, C., Reunanen, M., Skakkebaek, N.E., Toppari, J., 2004. Difference in prevalence of congenital cryptorchidism in infants between two Nordic countries. Lancet 363, 1264-1269.

Caron, P., Chauvin, S., Christin-Maitre, S., Bennet, A., Lahlou, N., Counis, R., Bouchard, P., Kottler, M.L., 1999. Resistance of hypogonadic patients with mutated GnRH receptor genes to pulsatile GnRH administration. J. Clin. Endocrinol. Metab. 84, 990-996.

Caronia, L.M., Martin, C., Welt, C.K., Sykiotis, G.P., Quinton, R., Thambundit, A., Avbelj, M., Dhruvakumar, S., Plummer, L., Hughes, V.A., Seminara, S.B., Boepple, P.A., Sidis, Y., Crowley, W.F.,Jr, Martin, K.A., Hall, J.E., Pitteloud, N., 2011. A genetic basis for functional hypothalamic amenorrhea. N. Engl. J. Med. 364, 215-225.

Damgaard, I.N., Jensen, T.K., Nordic Cryptorchidism Study Group, Petersen, J.H., Skakkebaek, N.E., Toppari, J., Main, K.M., 2008. Risk factors for congenital cryptorchidism in a prospective birth cohort study. PLoS One 3, e3051. 
de Roux, N., Young, J., Misrahi, M., Genet, R., Chanson, P., Schaison, G., Milgrom, E., 1997. A family with hypogonadotropic hypogonadism and mutations in the gonadotropin-releasing hormone receptor. N. Engl. J. Med. 337, 1597-1602.

Dewailly, D., Boucher, A., Decanter, C., Lagarde, J.P., Counis, R., Kottler, M.L., 2002. Spontaneous pregnancy in a patient who was homozygous for the Q106R mutation in the gonadotropin-releasing hormone receptor gene. Fertil. Steril. 77, 1288-1291.

Dode, C., Levilliers, J., Dupont, J.M., De Paepe, A., Le Du, N., Soussi-Yanicostas, N., Coimbra, R.S., Delmaghani, S., Compain-Nouaille, S., Baverel, F., Pecheux, C., Le Tessier, D., Cruaud, C., Delpech, M., Speleman, F., Vermeulen, S., Amalfitano, A., Bachelot, Y., Bouchard, P., Cabrol, S., Carel, J.C., Delemarrevan de Waal, H., Goulet-Salmon, B., Kottler, M.L., Richard, O., Sanchez-Franco, F., Saura, R., Young, J., Petit, C., Hardelin, J.P., 2003. Loss-of-function mutations in FGFR1 cause autosomal dominant Kallmann syndrome. Nat. Genet. 33, 463-465.

El Houate, B., Rouba, H., Imken, L., Sibai, H., Chafik, A., Boulouiz, R., Chadli, E., Hassar, M., McElreavey, K., Barakat, A., 2008. No association between T222P/LGR8 mutation and cryptorchidism in the Moroccan population. Horm. Res. 70, 236-239.

Elert, A., Jahn, K., Heidenreich, A., Hofmann, R., 2003. The familial undescended testis. Klin. Padiatr. 215, 40-45.

Ferlin, A., Zuccarello, D., Zuccarello, B., Chirico, M.R., Zanon, G.F., Foresta, C., 2008. Genetic alterations associated with cryptorchidism. JAMA 300, 2271-2276.

Foresta, C., Zuccarello, D., Garolla, A., Ferlin, A., 2008. Role of hormones, genes, and environment in human cryptorchidism. Endocr. Rev. 29, 560-580.

Gianetti, E., Tusset, C., Noel, S.D., Au, M.G., Dwyer, A.A., Hughes, V.A., Abreu, A.P., Carroll, J., Trarbach, E., Silveira, L.F., Costa, E.M., de Mendonca, B.B., de Castro, M., Lofrano, A., Hall, J.E., Bolu, E., Ozata, M., Quinton, R., Amory, J.K., Stewart, S.E., Arlt, W., Cole, T.R., Crowley, W.F., Kaiser, U.B., 
Latronico, A.C., Seminara, S.B., 2010. TAC3/TACR3 mutations reveal preferential activation of gonadotropin-releasing hormone release by neurokinin B in neonatal life followed by reversal in adulthood. J. Clin. Endocrinol. Metab. 95, 2857-2867.

Hadziselimovic, N.O., de Geyter, C., Demougin, P., Oakeley, E.J., Hadziselimovic, F., 2010. Decreased expression of FGFR1, SOS1, RAF1 genes in cryptorchidism. Urol. Int. 84, 353-361.

Koskimies, P., Virtanen, H., Lindstrom, M., Kaleva, M., Poutanen, M., Huhtaniemi, I., Toppari, J., 2000. A common polymorphism in the human relaxin-like factor (RLF) gene: no relationship with cryptorchidism. Pediatr. Res. 47, 538-541.

Krausz, C., Quintana-Murci, L., Fellous, M., Siffroi, J.P., McElreavey, K., 2000. Absence of mutations involving the INSL3 gene in human idiopathic cryptorchidism. Mol. Hum. Reprod. 6, 298-302.

Layman, L.C., Cohen, D.P., Jin, M., Xie, J., Li, Z., Reindollar, R.H., Bolbolan, S., Bick, D.P., Sherins, R.R., Duck, L.W., Musgrove, L.C., Sellers, J.C., Neill, J.D., 1998. Mutations in gonadotropin-releasing hormone receptor gene cause hypogonadotropic hypogonadism. Nat. Genet. 18, 14-15.

Lim, H.N., Raipert-de Meyts, E., Skakkebaek, N.E., Hawkins, J.R., Hughes, I.A., 2001. Genetic analysis of the INSL3 gene in patients with maldescent of the testis. Eur. J. Endocrinol. 144, 129-137.

Lin, L., Conway, G.S., Hill, N.R., Dattani, M.T., Hindmarsh, P.C., Achermann, J.C., 2006. A homozygous R262Q mutation in the gonadotropin-releasing hormone receptor presenting as constitutional delay of growth and puberty with subsequent borderline oligospermia. J. Clin. Endocrinol. Metab. 91, 5117-5121.

Main, K.M., Skakkebaek, N.E., Virtanen, H.E., Toppari, J., 2010. Genital anomalies in boys and the environment. Best Pract. Res. Clin. Endocrinol. Metab. 24, 279-289.

Nuti, F., Marinari, E., Erdei, E., El-Hamshari, M., Echavarria, M.G., Ars, E., Balercia, G., Merksz, M., Giachini, C., Shaeer, K.Z., Forti, G., Ruiz-Castane, E., Krausz, C., 2008. The leucine-rich repeat-containing 
G protein-coupled receptor 8 gene T222P mutation does not cause cryptorchidism. J. Clin. Endocrinol. Metab. 93, 1072-1076.

Pitteloud, N., Acierno, J.S.,Jr, Meysing, A.U., Dwyer, A.A., Hayes, F.J., Crowley, W.F.,Jr, 2005. Reversible kallmann syndrome, delayed puberty, and isolated anosmia occurring in a single family with a mutation in the fibroblast growth factor receptor 1 gene. J. Clin. Endocrinol. Metab. 90, 1317-1322.

Pitteloud, N., Hayes, F.J., Boepple, P.A., DeCruz, S., Seminara, S.B., MacLaughlin, D.T., Crowley, W.F.,Jr, 2002. The role of prior pubertal development, biochemical markers of testicular maturation, and genetics in elucidating the phenotypic heterogeneity of idiopathic hypogonadotropic hypogonadism. J. Clin. Endocrinol. Metab. 87, 152-160.

Raivio, T., Falardeau, J., Dwyer, A., Quinton, R., Hayes, F.J., Hughes, V.A., Cole, L.W., Pearce, S.H., Lee, H., Boepple, P., Crowley, W.F.Jr, Pitteloud, N., 2007. Reversal of idiopathic hypogonadotropic hypogonadism. N. Engl. J. Med. 357, 863-873.

Raivio, T., Toppari, J., Kaleva, M., Virtanen, H., Haavisto, A.M., Dunkel, L., Janne, O.A., 2003. Serum androgen bioactivity in cryptorchid and noncryptorchid boys during the postnatal reproductive hormone surge. J. Clin. Endocrinol. Metab. 88, 2597-2599.

Roh, J., Virtanen, H., Kumagai, J., Sudo, S., Kaleva, M., Toppari, J., Hsueh, A.J., 2003. Lack of LGR8 gene mutation in Finnish patients with a family history of cryptorchidism. Reprod. Biomed. Online 7, 400-406.

Sarfati, J., Guiochon-Mantel, A., Rondard, P., Arnulf, I., Garcia-Pinero, A., Wolczynski, S., Brailly-Tabard, S., Bidet, M., Ramos-Arroyo, M., Mathieu, M., Lienhardt-Roussie, A., Morgan, G., Turki, Z., Bremont, C., Lespinasse, J., Du Boullay, H., Chabbert-Buffet, N., Jacquemont, S., Reach, G., De Talence, N., Tonella, P., Conrad, B., Despert, F., Delobel, B., Brue, T., Bouvattier, C., Cabrol, S., Pugeat, M., Murat, A., Bouchard, P., Hardelin, J.P., Dode, C., Young, J., 2010. A comparative phenotypic study of kallmann syndrome patients carrying monoallelic and biallelic mutations in the prokineticin 2 or prokineticin receptor 2 genes. J. Clin. Endocrinol. Metab. 95, 659-669. 
Sato, N., Ohyama, K., Fukami, M., Okada, M., Ogata, T., 2006. Kallmann syndrome: somatic and germline mutations of the fibroblast growth factor receptor 1 gene in a mother and the son. J. Clin. Endocrinol. Metab. 91, 1415-1418.

Sinisi, A.A., Asci, R., Bellastella, G., Maione, L., Esposito, D., Elefante, A., De Bellis, A., Bellastella, A., Iolascon, A., 2008. Homozygous mutation in the prokineticin-receptor2 gene (Val274Asp) presenting as reversible Kallmann syndrome and persistent oligozoospermia: case report. Hum. Reprod. 23, 2380-2384.

Skakkebaek, N.E., Rajpert-De Meyts, E., Main, K.M., 2001. Testicular dysgenesis syndrome: an increasingly common developmental disorder with environmental aspects. Hum. Reprod. 16, 972-978.

Suomi, A.M., Main, K.M., Kaleva, M., Schmidt, I.M., Chellakooty, M., Virtanen, H.E., Boisen, K.A., Damgaard, I.N., Kai, C.M., Skakkebaek, N.E., Toppari, J., 2006. Hormonal changes in 3-month-old cryptorchid boys. J. Clin. Endocrinol. Metab. 91, 953-958.

Sykiotis, G.P., Hoang, X.H., Avbelj, M., Hayes, F.J., Thambundit, A., Dwyer, A., Au, M., Plummer, L., Crowley, W.F.,Jr, Pitteloud, N., 2010. Congenital idiopathic hypogonadotropic hypogonadism: evidence of defects in the hypothalamus, pituitary, and testes. J. Clin. Endocrinol. Metab. 95, 3019-3027.

Topaloglu, A.K., Reimann, F., Guclu, M., Yalin, A.S., Kotan, L.D., Porter, K.M., Serin, A., Mungan, N.O., Cook, J.R., Ozbek, M.N., Imamoglu, S., Akalin, N.S., Yuksel, B., O'Rahilly, S., Semple, R.K., 2009. TAC3 and TACR3 mutations in familial hypogonadotropic hypogonadism reveal a key role for Neurokinin B in the central control of reproduction. Nat. Genet. 41, 354-358.

Vaaralahti, K., Wehkalampi, K., Tommiska, J., Laitinen, E.M., Dunkel, L., Raivio, T., 2011. The role of gene defects underlying isolated hypogonadotropic hypogonadism in patients with constitutional delay of growth and puberty. Fertil. Steril. DOI: 10.1016/j.fertnstert.2010.12.059.

Virtanen, H.E., Bjerknes, R., Cortes, D., Jorgensen, N., Rajpert-De Meyts, E., Thorsson, A.V., Thorup, J., Main, K.M., 2007a. Cryptorchidism: classification, prevalence and long-term consequences. Acta Paediatr. 96, 611-616. 
Virtanen, H.E., Cortes, D., Rajpert-De Meyts, E., Ritzen, E.M., Nordenskjold, A., Skakkebaek, N.E.,

296 Toppari, J., 2007b. Development and descent of the testis in relation to cryptorchidism. Acta Paediatr. 96,

$297 \quad 622-627$.

298 Weidner, I.S., Moller, H., Jensen, T.K., Skakkebaek, N.E., 1999. Risk factors for cryptorchidism and

299 hypospadias. J. Urol. 161, 1606-1609.

300 Zenaty, D., Bretones, P., Lambe, C., Guemas, I., David, M., Leger, J., de Roux, N., 2006. Paediatric

301 phenotype of Kallmann syndrome due to mutations of fibroblast growth factor receptor 1 (FGFR1). Mol.

302 Cell. Endocrinol. 254-255, 78-83.

303 
305 Highlights

306

- We investigated the defects in FGFR1, GNRHR, PROK2, PROKR2, TAC3, and TACR3 in 54

308 subjects with isolated cryptorchidism.

309

310

311

312

313

314

315

4

- Two subjects carried heterozygous GNRHR mutations (Q106R and R262Q), but these changes were also present in controls with similar frequency.

- None of the subjects carried mutation(s) in FGFR1, PROK2, PROKR2, TAC3 or TACR3.

- It is unlikely that mutations in these genes would significantly contribute to the prevalence of isolated cryptorchidism. 